\title{
Perumusan Indeks Penilaian 5A (Attraction, Accessibilities, Amenities, Accommodation Dan Awareness) Untuk Obyek Wisata Pantai Lasiana Kupang Provinsi NTT
}

\author{
Formulation of the 5A Index (Attraction, Accessibilities, \\ Amenities, Accommodation and Awareness) for Lasiana \\ Beach Tourism Object in Kupang NTT Province
}

Yuan Valentino Elim, Suci Istiqlaal, Aprianus P. Modena

* Corresponding author: Yuan Valentino Elim

E-mail: charistaelim@gmail.com

Naskah Diterima : 10 Desember 2019; Di-review : 19 Desember 2019; Dimuat: 30 Desember 2019

DOI :

Copyright @FLOBAMORA 2019

\begin{abstract}
This study aims to find indicators that influence the 5A variables (Atraction, Accessibility, Amenity, Acommodation and Awareness) on the Kupang Lasiana tourist attraction and determine the index of each 5A variable (Atraction, Accessibility, Amenity, Acommodations and Awareness) on the object Lasiana Beach Kupang tour. This research method is a mixed method and analyzed using multiple regression with variables including Attractions, Accessibility, Amenities, Accommodation and Awareness. The results showed that the value of the natural tourism potential index (IPWA) obtained a score of 67, 4160, the cultural tourism potential index (IPWB), of - 4.3459, the artificial tourism potential index (IPWBU) of -0.58878 , the Accessibility potential index (IPAc) amounted to 3.8016, the Aminities potential index (IPAm) was - 381,157, the accommodation potential index (IPAk) was 2.79468, the potential awareness index (IPAw) was - 18.4035.
\end{abstract}

Keywords : Tourism, Lasiana Beach, 5A, and Kupang

\begin{abstract}
Abstrak
Penelitian ini bertujuan untuk menemukan indikator yang berpengaruh terhadap variable 5A (Atraction, Accessibility, Amenitas, Acommodations dan Awareness) pada obyek wisata Pantai Lasiana Kupang dan menentukan indeks dari masingmasing variabel 5A (Atraction, Accessibility, Amenitas, Acommodations dan Awareness) pada obyek wisata Pantai Lasiana Kupang. Metode penelitian ini adalah mixed method dan dianalisis menggunakan regresi berganda dengan variable meliputi Attractions, Accessibilities, Amenities, Acomodation dan Awareness. Hasil penelitian menunjukkan bahwa nilai indeks potensi wisata alam (IPWA) diperoleh skor sebesar 67, 4160, indeks potensi wisata budaya (IPWB), sebesar - 4,3459, indeks potensi wisata buatan (IPWBU) sebesar -0.58878, indeks potensi Aksesibilitas (IPAc) sebesar 3,8016, indeks potensi Aminities (IPAm) sebesar- 381.157, indeks potensi akomodasi (IPAk) sebesar2,79468, indeks potensi awareness (IPAw) sebesar - 18,4035.
\end{abstract}

Kata Kunci:Pariwisata, Pantai Lasiana, 5A, dan Kupang

\section{Pendahuluan}

Arah gerak perkembangan pariwisata global saat ini mulai beralih kepada pengembangan pariwisata yang berkelanjutan (sustainable tourism). Titik berat pengembangan pariwisata yang berkelanjutan terletak pada upaya untuk menjaga agar pariwisata tidak saja menarik dan menguntungkan pada masa sekarang tetapi menjadi lestari untuk masa yang akan datang. World Tourism Organization (WTO) membatasi pariwisata berkelanjutan sebagai pariwisata yang; 1) memperhitungkan secara penuh dampak ekonomi, sosial budaya dan lingkungan pada masa sekarang dan masa akan datang; dan 2) menjawab kebutuhan pengunjung, industri pariwisata, lingkungan dan komunitas lokal. Dari definisi ini, ada tiga hal besar yang menjadi tema penting dalam diskusi tentang pariwisata yang berkelanjutan yaitu; ekonomi, budaya dan lingkungan. 
Pada aspek ekonomi, konsentrasi pengembangan pariwisata berkelanjutan tertuju pada pemanfaatan ekonomi dari aktivitas pariwisata bagi semua pemangku kepentingan secara merata, terutama bagi masyarakat sekitar yang berorientasi jangka panjang, pada masa kini dan masa akan datang. Aspek ini berhubungan dengan bagaimana kontribusi pariwisata bagi pendapatan masyarakat lokal, peluang kerja untuk masyarakat lokal, akses masyarakat lokal pada atraksi wisata alam, budaya dan buatan, edukasi sadar wisata oleh pihak terkait bagi masyarakat lokal dan beberapa hal lainnya.

Pada aspek budaya, konsentrasi pengembangan pariwisata berkelanjutan berkenaan dengan upaya pelestarian budaya. Upaya ini secara terperinci mencakup perlindungan atraksi wisata terutama otentisitas budaya secara jangka panjang, pengelolaan pengunjung dalam destinasi wisata misalnya melalui sapta pesona, perlindungan destinasi terhadap perilaku pengunjung dan perlindungan warisan budaya yang bersentuhan dengan penghormatan dan toleransi antara masyarakat budaya dan wisatawan serta beberapa hal lainnya.

Sedangkan pada aspek lingkungan, konsentrasi terarah pada upaya pelestarian lingkungan dari aktivitas pariwisata yang berpotensi destruktif terhadap lingkungan. Upaya ini secara khusus berkenaan dengan bagaimana memanfaatkan sumberdaya lingkungan yang menjadi elemen kunci dalam pengembangunan pariwisata secara optimal, menjaga proses ekologi dan membantu konservasi alam serta keanekaragaman hayati.

Dalam rangka untuk mencapai upaya-upaya tersebut, dibutuhkan sebuah kerangka pengembangan destinasi wisata berkelanjutan yang komprehensif. Secara internasional, Cooper, dkk. (dalam Sunaryo, 2013: 159) memperkenalkan konsep 4 A + 1 I sebagai salah satu jalan untuk mencapai upaya tersebut. konsep tersebut yaitu 1) Atraction atau daya tarik wisata, 2) Accessibility atau aksesibilitas, 3) Amenitas yang mencakup fasilitas penunjang dan pendukung, 4) Ancillary Service atau fasilitas umum dan 5) Institutions atau kelembagaan.

Laiskodat (2018) melengkapi dan mengkontekstualisasikan konsep ini menambahkan term Awareness ke dalam konsep 4A sehingga menjadi 5A dan dengan menambahkan accommodation sebagai salah satu konsep untuk menggantikan ancillary service. Istilah ini ingin membahasakan tentang masyarakat yang sadar wisata. Konsep Awareness ini mencakup kesadaran masyarakat lokal terutama di sekitar destinasi wisata untuk terlibat dalam pengembangan pariwisata secara ekonomi, misalnya dengan menciptakan usaha ekonomi kreatif, terlibat dari sisi budaya misalnya dengan menjaga dan melestarikan kekayaan budaya yang berdaya tarik wisata serta terlibat dari sisi lingkungan misalnya dengan turut aktif menjaga kelestarian, kebersihan dan keindahan lingkungan destinasi wisata.

Di Nusa Tenggara Timur, obyek berdaya tarik wisata yang mencakup wisata alam, budaya dan buatan sangat potensial secara kuantitas dan kualitas untuk dikembangkan secara berkelanjutan guna peningkatan pendapatan masyarakat. BPS NTT (2018) mencatat bahwa terdapat setidaknya 443 daya tarik wisata menurut tema wisata, entah wisata alam (nature), budaya (culture), minat khusus (special interest) dan wisata buatan (artificial). Kuantitas daya tarik wisata ini seharusnya secara optimal berkontribusi terhadap jumlah kunjungan wisata di NTT. Dari catatan BPS NTT dapat dilihat bahwa memang terjadi peningkatan angka kunjungan wisatawan ke NTT dari waktu ke waktu, akan tetapi jumlah itu masih selalu berada di bawah daerahdaerah lainnya di Indonesia. NTB adalah salah satunya. Pada tahun 2016, jumlah kunjungan wisatawan ke NTT mencapai 430.582 kunjungan, sedangkan provinsi NTB mencapai 3.094.437.

Realitas ini menunjukkan bahwa pengembangan pariwisata di NTT membutuhkan suatu kerangka strategi pengembangan yang andal juga mumpuni. Konsep 5 A dinilai tepat untuk itu dimana konsep ini menyajikan pemetaan/penilaian atas kondisi riil keadaan suatu obyek wisata; dari sisi keunikan, keindahan, dan keeksotikan suatu atraksi wisata, ketersediaan aksesilibitas seperti akses jalan penghubung, penunjuk lokasi, akses transportasi, dll.; ketersediaan fasilitas penunjang dan pendukung seperti tempat sampah, toilet, tempat kuliner, ATM, sarana telekomonikasi, tempat ibadat, sarana bermain anak dll.; ketersediaan fasilitas akomodasi seperti. Penginapan/homestay; dan kesadaran serta peran serta masyarakat dalam mendukung pengembangan pariwisata. Secara lebih spesifik, penilaian atau pemberian nilai atas ketersediaan 5 A dalam strategi pengembangan pariwisata berkelanjutan, dapat dijadikan sebagai pedoman untuk menentukan strategi yang tepat dalam pengembangan pariwisata secara berkelanjutan.

Kajian ini bertujuan untuk menemukan indicator yang berpengaruh terhadap variabel $5 \mathrm{~A}$ (Atraction, Accessibility, Amenitas, Acommodations dan Awareness) pada obyek wisata Pantai Lasiana Kupang dan menentukan indeks dari masing-masing variabel 5 A (Atraction, Accessibility, Amenitas, Acommodations dan Awareness) pada obyek wisata Pantai Lasiana Kupang.

\section{Kerangka Teori}

Pembangunan pariwisata perlu diarahkan untuk memberikan dampak positif dari sektor ekonomi, budaya dan lingkungan bagi semua stakeholder yang terlibat di dalamnya.Oleh karena itu, dibutuhkan kerangka pengembangan pariwisata yang mengarahkan upaya tersebut. Kerangka pengembangan destinasi pariwisata yang digunakan 
dalam penelitian ini menggunakan konsep 5A yang terdiri dari, attraction, accessibility, amenity, acommodations, dan awareness. Kelima variabel ini berkaitan satu sama lain dalam menciptakan destinasi pariwisata yang unggul.

Provinsi NTT memiliki berbagai daya tarik pariwisata baik alam, budaya dan buatan.Kendati demikian, belum semua destinasi wisata memenuhi standar dalam kerangka pengembangan destinasi pariwisata.Oleh karena itu, perbaikan pada masingmasing variabel mutlak dibutuhkan.Untuk membantu upaya perbaikan ini dibutuhkan instrumen yang membantu mengukur sebuah destinasi berdasarkan variabel $5 \mathrm{~A}$ tersebut.Oleh karena itu perlu disusun indeks kerangka pengembangan pariwisata. Berikut ini adalah gambar kerangka pikir:

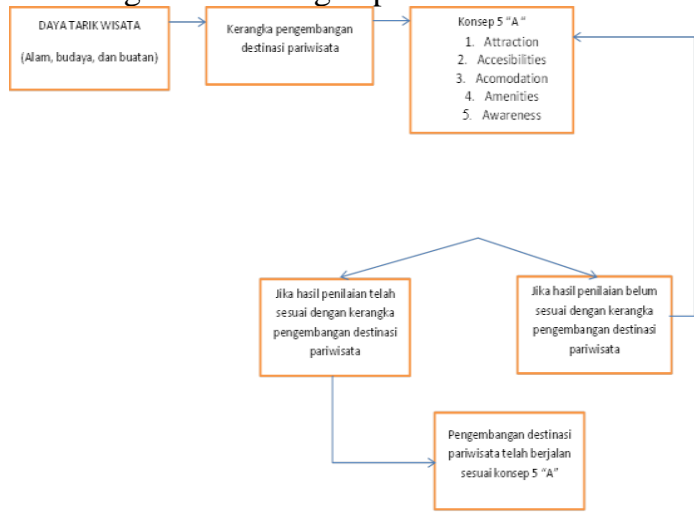

Gambar 1. Bagan Kerangka Pemikiran

\section{Metode}

Pengkajian ini dilakukan pada obyek wisata pantai lasiana yang berlokasi di Kota Kupang Provinsi Nusa Tenggara Timur. Pemilihan tempat penelitian dilakukan secara sengaja (purposive) dengan pertimbangan bahwa obyek wisata tersebut berpotensi untuk dikembangkan.

Metode deskriptif digunakan untuk menganalisis data secara kualitatif. Hasil kuesioner yang diperoleh, selain dianalisis dengan regresi, juga dianalisis secara deskriptif. Analisis deskriptif dalam penelitian ini dimaksudkan untuk mengetahui persepsi pengunjung mengenai potensi obyek wisata pantai lasiana yang mencakup 5A yaitu Attractions, Accessibilities, Amenities, Acomodation dan Awareness. Disamping itu, penggunaan analisis deskriptif juga dapat menghasilkan saran-saran yang merupakan pemikiran pengunjung. Saran tersebut bisa dimanfaatkan oleh pihak manajemen demi perbaikan dan pengembangan objek wisata pantai lasiana.

Berdasarkan sumber perolehan data, maka jenis data yang digunakan dalam penulisan penelitian adalah data primer dan data sekunder. Data primer merupakan data yang diperoleh langsung dari sumber atau objek penelitian, melalui : 1) pengamatan langsung, untuk mengetahui kondisi fisik usaha serta proses penggunaan produk/jasa oleh wisatawan, 2) wawancara langsung dengan pihak manajemen usaha untuk mengetahui permasalahan serta kendala yang dihadapi, dan 3) wawancara dengan konsumen serta pengisian kuesioner, untuk mengetahui karakteristik dan penilaian pengunjung. Data sekunder adalah jenis data yang sudah diterbitkan, berupa bahan pustaka, laporan perusahaan dan instansi-instansi yang terkait dengan bidang kepariwisataan antara lain Dinas Pariwisata baik untuk tingkat Nasional maupun provinsi Nusa Tenggara Timur.

Berdasarkan sifat data yang diperoleh, jenis data yang digunakan adalah data kualitatif dan data kuantitatif. Data kualitatif merupakan data-data nonangka (non-numerik) berupa keterangan-keterangan mengenai kondisi objek wisata pantai lasiana, karakteristik konsumen, penilaian konsumen dan sebagainya yang berhubungan dengan penelitian. Data kuantitatif merupakan data angka atau numerik, seperti omzet usaha, jumlah kunjungan wisatawan dan semua keterangan yang berupa angka.

Penentuan jumlah sampel yang diteliti digunakan metode slovin yang dikutip dari Umar (2003), dengan rumus:

$$
\mathrm{n}=\frac{\mathrm{N}}{1+\left(\mathrm{N}+\mathrm{e}^{2}\right)}=\frac{2400}{1+2400(10 \%)^{2}}=96 \text { responden } \approx 1
$$

dimana $n$ adalah jumlah sampel yang akan diambil dari sejumlah $N$ populasi dan $e$ adalah tingkat kesalahan yang diharapkan. Berdasarkan data jumlah konsumen yang berkunjung ke objek wisata pantai lasiana pada tahun 2017, diperoleh informasi bahwa jumlah konsumen rata-rata setiap bulannya diperkirakan sebanyak 2400 orang (Wairo, 2017). Dengan menggunakan data tersebut dan nilai kritis sebesar 10 persen (nilai kritis penelitian deskriptif) maka diperoleh jumlah sampel sebanyak 96 orang dan dibulatkan menjadi 100 orang.

Metode analisis data yang digunakan dalam penelitian bertujuan untuk mengukur atribut-atribut potensi objek wisata pantai lasiana yang mempengaruhi konsumen dalam berkunjung. Metode yang digunakan adalah Analisis Deskriptif dan Regresi Logistik, dimana data yang diperoleh diolah dengan bantuan software SPSS.20.00.

\section{Hasil dan Pembahasan}

Penelitian ini dilakukan di Objek Wisata Pantai Lasiana (OWPL) dengan menggunakan analisis Regresi Logistik untuk mengidentifikasi indikator yang mempengaruhi keputusan wisatawan untuk berkunjung ke objek wisata pantai lasiana berdasarkan potensi attractions, accessibilities, acomodation, amenities, dan awareness.

Analisis Regresi Logistik dilakukan melalui beberapa tahap utama, yaitu menentukan model, melakukan pendugaan terhadap masing-masing koefisien dalam model, melakukan uji signifikansi masing-masing variabel penjelas dalam model sekaligus menilai kelayakan model tersebut. Selanjutnya melakukan analisis terhadap indikator 
yang signifikan mempengaruhi keputusan wisatawan untuk melakukan kunjungan ulang ke objek wisata pantai lasiana.

\section{a) ATTRACTION}

Atraksi destinasi merupakan elemen-elemen yang terkandung dalam destinasi dan lingkungan di dalamnya yang secara individual atau kombinasinya memegang peran penting dalam memotivasi wisatawan untuk berkunjung ke destinasi tersebut. Atraksi wisata di kelompokan ke dalam 3 kategori yaitu atraksi wisata alam, wisata budaya dan wisata buatan.

\section{1) Uji Signifikansi Model}

Uji signifikansi model adalah untuk mengetahui pengaruh variabel bebas (indikator) terhadap variabel tidak bebas secara bersama-sama (overal) di dalam model dengan menggunakan Uji Likelihood Ratio.

\section{- Wisata Alam}

Berdasarkan perhitungan analisis logistic biner, didapatkan hasil bahwa Ho ditolak karena p-value > $\alpha(0.500>0,1)$, maka dapat disimpulkan bahwa paling sedikit ada satu indikator memberi pengaruh signifikan terhadap variabel wisata alam (Attraction).

Tabel 1 Uji Signifikansi Model Atraksi

\begin{tabular}{|l|r|r|c|}
\hline \multicolumn{4}{|c|}{ Wisata Alam } \\
Step & $\begin{array}{c}\text { Cox \& } \\
\text { likelihood }\end{array}$ & $\begin{array}{c}\text { Snell R } \\
\text { Square }\end{array}$ & $\begin{array}{c}\text { Nagelkerke R } \\
\text { Square }\end{array}$ \\
\hline 1 & $.500^{\mathrm{a}}$ & .252 & 1.000 \\
\hline
\end{tabular}

\section{- Wisata Budaya}

Berdasarkan hasil perhitungan, nilai statistik G2 ini mengikuti distribusi Khi-kuadrat dengan derajat bebas $\mathrm{p}$ sehingga Ho ditolak karena $\mathrm{p}$-value $>\alpha$ $(24.188>0,1)$, yang artinya terdapat paling sedikit ada satu atau lebih indikator yang berpengaruh signifikan terhadap variabel wisata budaya (Attraction).

Tabel 2 Uji Signifikansi Model Atraksi Wisata Budaya

\begin{tabular}{|l|r|r|c|}
\hline Step & $\begin{array}{c}-2 \text { Log } \\
\text { likelihood }\end{array}$ & $\begin{array}{c}\text { Cox \& Snell } \\
\text { R Square }\end{array}$ & $\begin{array}{c}\text { Nagelkerke } \\
\text { R Square }\end{array}$ \\
\hline 1 & $24.188^{\mathrm{a}}$ & .271 & .633 \\
\hline
\end{tabular}

\section{- Wisata Buatan}

Berdasarkan hasil analisis, nilai statistik G2 ini mengikuti distribusi Khi-kuadrat dengan derajat bebas $\mathrm{p}$ sehingga Ho ditolak karena $\mathrm{p}$-value $>\alpha$ $(95.436>0,1)$, yang artinya terdapat paling sedikit ada satu atau lebih indikator yang berpengaruh signifikan terhadap variable wisata buatan (Attraction).

Tabel 3 Uji Signifikansi Model Atraksi Wisata Buatan

\begin{tabular}{|c|c|c|c|}
\hline & -2 Log & Cox \& Snell & Nagelkerke R \\
Step & likelihood & R Square & Square \\
\hline
\end{tabular}

\begin{tabular}{|l|r|r|r|}
\hline 1 & $95.436^{\mathrm{a}}$ & .318 & .432 \\
\hline
\end{tabular}

\section{2) Uji Parsial dan Pembentukan Model}

Pada umumnya, tujuan analisis statistik adalah untuk mencari model yang cocok dan keterpautan yang kuat antara model dengan data yang ada. Pengujian keberartian parameter (koefisien $\beta$ ) secara parsial dapat dilakukan melalui Uji Wald dengan hipotesisnya sebagai berikut:

Ho: $\beta \mathrm{j}=0$ (variabel bebas ke $\mathrm{j}$ tidak mempunyai pengaruh secara signifikan terhadap variabel tidak bebas

H1: $\beta \mathrm{j} \neq 0$ (variabel bebas ke $\mathrm{j}$ mempunyai pengaruh secara signifikan terhadap variabel tidak bebas)

\section{- Wisata Alam}

Variabel wisata alam terdiri keindahan Pantai (WA1), pemandangan Laut (WA2), pemandangan Sunset Dan Sunrise (WA3), keindahan Pasir pantai (WA4), kenyamanan cuaca di pantai (WA5), keberadaan tumbuhan pantai (WA6), dan keindahan air laut (WA7). Variabel atraksi wisata alam ini akan dilakukan uji wald untuk mengetahui indikator mana saja yang berpengaruh terhadap variabel wisata alam tersebut. Hasil analisis uji wald dapat dilihat pada tabel di bawah ini :

Tabel 4 Uji Wald Atraksi Wisata Alam

\begin{tabular}{|cc|c|c|c|}
\hline & & B & Wald & Sig. \\
\hline Step & WA1 & 65.161 & 5.566 & .0994 \\
$1^{\mathrm{a}}$ & WA2 & 15.385 & 4.566 & .0999 \\
& WA3 & 14.695 & 5.126 & .0999 \\
& WA4 & -1.000 & 9.334 & .0700 \\
\hline & WA5 & 15.101 & 3.655 & .0996 \\
& WA6 & 15.861 & 3.221 & .0996 \\
& WA7 & 33.643 & 3.233 & .0997 \\
& Constant & -62.744 & 33.000 & .995 \\
\hline
\end{tabular}

Berdasarkan hasil analisis, indikator AW1 s/d AW7 memiliki nilai wald $\neq 0$, yang artinya indikator tersebut mempunyai pengaruh secara signifikan terhadap variabel wisata alam (Attraction). Dari dua pengujian yang dilakukan terhadap perolehan data; uji signifikansi model dan uji parsial dan pembentukan model, ditemukan bahwa semua indikator mempunyai pengaruh secara signifikan terhadap variabel wisata alam. Hal ini berarti bahwa, untuk menjaga dan mengembangkan potensi wisata alam di obyek wisata Pantai Lasiana, seluruh indikator inilah yang harus mendapat perhatian serius. Indikator tersebut adalah kejernihan air laut, kebersihan pasir pantai, dan keindahan tumbuhan di sekitar pantai. 


\section{- Wisata Budaya}

Variabel wisata budaya terdiri dari suguhan cerita rakyat (WB1), suguhan musik/teater (WB2), suguhan nilai agama (WB3), dan suguhan budaya lokal (WB4). Hasil uji wald atraksi wisata budaya dapat dilihat pada tabel di bawah ini :

Tabel 5 Uji Wald Atraksi Wisata Budaya

\begin{tabular}{|cc|c|c|c|}
\hline & & B & Wald & Sig. \\
\hline Step & WB1 & 1.352 & .501 & .479 \\
$1^{\mathrm{a}}$ & WB2 & 5.064 & 14.707 & .000 \\
& WB3 & .983 & .153 & .696 \\
& WB4 & 1.277 & .551 & .458 \\
& Constant & -4.751 & 18.448 & .000 \\
\hline
\end{tabular}

Berdasarkan hasil uji wald, hanya indikator suguhan nilai seni (music/teater) (WB2) yang berpengaruh secara signifikan terhadap variabel wisata budaya (Attraction).

\section{- Wisata Buatan}

Variabel wisata buatan terdiri dari Kenyamanan Bangunan (Lopo) Di Lasiana (WBU1), kenyamanan taman/ kebun di Lasiana (WBU2), kenyamanan bangunan konvensi/tempat pertemuan (WBU3), dan kenyamanan bangunan kantin/ kuliner (WBU4). Hasil uji wald dapat dilihat pada tabel di bawah ini:

Tabel 6 Uji Wald Atraksi Wisata Buatan

\begin{tabular}{|cc|c|c|c|}
\hline & & B & Wald & Sig. \\
\hline & WBU1 & 2.476 & 14.118 & .000 \\
& WBU2 & -2.475 & 11.025 & .001 \\
Step & WBU3 & 1.201 & 3.342 & .068 \\
$1^{\mathrm{a}}$ & WBU4 & 1.485 & 5.872 & .015 \\
& Constant & -2.236 & 19.091 & .000 \\
\hline
\end{tabular}

Berdasarkan hasil uji wald, indikator WBU1 s/d WBU4 mempunyai pengaruh secara signifikan terhadap variabel wisata buatan (Attraction).

\section{3) Odds Ratio}

Nilai odds rasio menjelaskan peluang responden untuk berkunjung kembali ke Obyek Wisata Pantai Lasiana (OWPL) berdasarkan masing- masing indikator tersebut di atas. Di bawah ini akan dilakukan perhitungan odds ratio untuk atraksi wisata alam, wisata budaya, dan wisata buatan

\section{- Wisata Alam}

Berdasarkan hasil perhitungan odds ratio, diketahui bahwa nilai odds rasio terbesar terdapat pada indikator "Keindahan Air Laut" dan yang terkecil terdapat pada indikator "Keindahan Pasir Pantai". Semakin besar nilai odds pada masing- masing indikator, maka semakin besar pula peluang responden untuk berkunjung kembali karena alasan indikator tersebut.

Nilai $\mathrm{P}$ dari hasil perhitungan odds ratio menunjukkan nilai signifikasi masing-masing indikator terhadap variable wisata alam (Attractions). Hasil perhitungan menunjukkan bahwasannya semua indikator berpengaruh secara signifikan, sehingga seluruh indikator tersebut dapat digunakan dalam perumusan indeks. Hasil perhitungan odds ratio dapat dilihat pada tabel di bawah ini :

Tabel 7 Hasil Perhitungan Odds Ratio Atraksi Wisata Alam

\begin{tabular}{|l|c|c|}
\hline \multicolumn{1}{|c|}{ Variabel } & Koefisien & Nilai P \\
\hline Keindahan Pantai (WA1) & 65.161 & .0994 \\
\hline $\begin{array}{l}\text { Pemandangan Laut } \\
\text { (WA2) }\end{array}$ & 15.385 & .0999 \\
\hline $\begin{array}{l}\text { Pemandangan Sunset Dan } \\
\text { Sunrise (WA3) }\end{array}$ & 14.695 & .0999 \\
\hline $\begin{array}{l}\text { Keindahan Pasir Pantai } \\
\text { (WA4) }\end{array}$ & -1.000 & .0700 \\
\hline $\begin{array}{l}\text { Kenyamanan Cuaca Di } \\
\text { Pantai (WA5) }\end{array}$ & 15.101 & .0996 \\
\hline $\begin{array}{l}\text { Keberadaan Tumbuhan } \\
\text { Pantai (WA6) }\end{array}$ & 15.861 & .0996 \\
\hline $\begin{array}{l}\text { Keindahan Air Laut } \\
\text { (WA7) }\end{array}$ & 33.643 & .0997 \\
\hline
\end{tabular}

Dengan demikian, berdasarkan hasil uji regresi logistic biner, maka didapatkan rumus indeks potensi wisata alam (Attractions) adalah sebagai beikut :

Indeks Potensi Wisata Alam (IPWA) $=-62,744+$ $65,161 \mathrm{WA} 1+15.385 \mathrm{WA} 2+14.695 \mathrm{WA} 3-1 \mathrm{WA} 4+$ 15.101 WA5+ 15.861WA6+ 33.643WA7

IPWA $=-62,744+65,161(0,95)+15.385(0,92)+$ $14.695(0,91)-1(0,77)+15,101(0,78)+15,861$ $(0,58)+33,643(0,61)=\mathbf{6 7}, 4160$

Nilai cut off $=0$

Berdasarkan nilai cut off tersebut dapat dibuat 2 kategori yaitu:

Skor indeks $<\mathbf{0}=$ diprediksi potensi wisata alam belum memadai

Skor indeks $\geq \mathbf{0}=$ diprediksi potensi wisata alam sudah memadai

Berdasarkan penilaian atas indeks potensi wisata alam (IPWA) diperoleh skor sebesar 67, 4160. Hal ini berarti bahwa kondisi wisata alam di OWPL sudah cukup memadai, meliputi keindahan pantai dan pemandangan lautnya, pemandangan sunset dan sunrise yang indah, cuaca pantai yang nyaman untuk dikunjungi. Hal ini berkaitan erat dengan keberadaan tumbuhan pantai yaitu pohon lontar yang tumbuh di area wisata serta kejernihan air laut pantai lasiana. Keindahan ini menjadi modal alam yang dimiliki oleh obyek wisata Pantai Lasiana yang perlu dijaga dan dikembangkan. Hal utama yang dapat dilakukan pemerintah adalah menjaga kebersihan dan kenyamanan pantai, yang dapat ditempuh dari dua 
sisi; 1) dari sisi manusia; perlu melibatkan keaktifan masyarakat sekitar, mengiatkan dan mendorong kelompok sadar wisata, atau menambah petugas khusus penjaga kebersihan pantai. 2) dari sisi nonmanusia; perlu ada papan berisi himbauan tertulis untuk menjaga kebersihan pantai, kelestarian lingkungan dan sebagainya yang ditempatkan pada beberapa titik di sekitar pantai. Perlu juga memperbanyak tempat-tempat sampah dan menata secara khusus mekanisme pengangkutan sampah. Pohon-pohon hias tertentu, di samping pohon lontar juga perlu ditanam di wilayah pantai. Di samping itu, ada salah satu indikator yang perlu mendapat perbaikan yaitu kondisi pasir di pantai Lasiana. Upaya ini dapat ditempuh dengan melakukan pengayakan (penyaringan) dari bahan pengotor (sampah) seperti sampah plastik, bebatuan dan kotoran hewan.

\section{- Wisata Budaya}

Berdasarkan hasil perhitungan odds ratio, diperoleh nilai koefisien masing-masing indikator untuk variabel wisata budaya (attraction) yang berguna dalam perumusan indeks potensi wisata budaya (Attractions) OWPL.

Nilai $\mathrm{P}$ dari hasil perhitungan odds ratio menunjukkan nilai signifikasi masing- masing indikator terhadap variabel wisata budaya (Attractions) OWPL. Hasil perhitungan menunjukkan bahwa indikator suguhan music/teater (WB2) berpengaruh secara signifikan, sedangkan tiga indikator lainnya (WB1, WB3, dan WB4) tidak berpengaruh secara signifikan terhadap variabel wisata budaya (Attraction), sehingga hanya indikator WB2 yang digunakan dalam perumusan indeks. Hasil perhitungan odds ratio dapat dilihat pada tabel dibawah ini :

Tabel 8 Hasil Perhitungan Odds Ratio Atraksi Wisata Budaya

\begin{tabular}{|l|c|c|}
\hline \multicolumn{1}{|c|}{ Variabel } & Koefisien & Nilai P \\
\hline $\begin{array}{l}\text { Suguhan Cerita Rakyat } \\
\text { (WB1) }\end{array}$ & 1.352 & .479 \\
\hline $\begin{array}{l}\text { Suguhan Musik / Teater } \\
\text { (WB2) }\end{array}$ & 5.064 & .000 \\
\hline $\begin{array}{l}\text { Suguhan Nilai Agama } \\
\text { (WB3) }\end{array}$ & .983 & .696 \\
\hline $\begin{array}{l}\text { Suguhan Budaya Local } \\
\text { (WB4) }\end{array}$ & 1.277 & .458 \\
\hline
\end{tabular}

Dengan demikian, berdasarkan hasil uji regresi logistic biner, maka didapatkan rumus indeks potensi wisata budaya (Attractions) adalah sebagai beikut : Indeks Potensi Wisata Budaya $($ IPWB $)=-4.751+$ $5.064 \mathrm{WB} 2$

IPWB $=-4,751+5,064(0,08)=\mathbf{- 4 , 3 4 5 9}$

Nilai cut off $=0$
Berdasarkan nilai cut off tersebut dapat dibuat 2 kategori yaitu:

Skor indeks $<\mathbf{0}=$ diprediksi potensi wisata budaya belum memadai

Skor indeks $\geq \mathbf{0}=$ diprediksi potensi wisata budaya sudah memadai

Berdasarkan hasil penilaian atas indeks potensi wisata budaya (IPWB), skor yang didapatkan adalah sebesar - 4,3459. Hal ini berarti bahwa kondisi wisata budaya di pantai lasiana dirasa kurang memadai untuk menarik minat wisatawan berkunjung ke OWPL. Ada beberapa hal yang dapat dilakukan oleh pemerintah, untuk meningkatkan potensi wisata budaya terkait suguhan music/ teater yang memang secara signifikansi berpengaruh terhadap potensi wisata budaya di OWPL. Beberapa hal tersebut adalah dari sisi manusia; perlu adanya pemberdayaan masyarakat berbasis pariwisata, pengaktifan kelompok sadar wisata, pelibatan kerjasama sanggarsanggar budaya, komunitas-komunitas anak muda kreatif, dll. Dari sisi non-manusia; pemerintah juga perlu mendirikan dan menambah sarana prasarana pertunjukan seni budaya di sekitar pantai Lasiana, serta membuat jadwal acara pertunjukan musik disetiap hari libur (weekend).

\section{- Wisata Buatan}

Berdasarkan hasil perhitungan, diperoleh nilai koefisien masing-masing indikator untuk variabel wisata buatan (attraction) yang berguna dalam perumusan indeks potensi wisata buatan (Attractions) OWPL.

Nilai $\mathrm{P}$ dari hasil perhitungan odds ratio menunjukkan nilai signifikasi masing- masing indikator terhadap variabel wisata buatan (Attractions) di pantai lasiana. Hasil perhitungan menunjukkan bahwasannya semua indikator berpengaruh secara signifikan terhadap variabel wisata buatan (Attraction), sehingga semua indikator dapat digunakan dalam perumusan indeks.

Berdasarkan hasil perhitungan, diketahui bahwa nilai odds ratio terbesar terdapat pada indikator "Kenyamanan Bangunan (Lopo) Di Lasiana (WBU1)" dan yang terkecil terdapat pada indikator "Kenyamanan Taman/Kebun Di Lasiana (WBU2)". Semakin besar nilai odds pada masing- masing indikator, maka semakin besar pula peluang responden untuk berkunjung kembali karena alasan indikator tersebut. Hasil perhitungan odds ratio dapat dilihat pada tabel dibawah ini :

Tabel 9 Hasil Perhitungan Odds Ratio Atraksi Wisata Buatan

\begin{tabular}{|l|c|c|}
\hline \multicolumn{1}{|c|}{ Variabel } & Koefisien & Nilai P \\
\hline Wisata Buatan & & \\
\hline $\begin{array}{l}\text { Kenyamanan Bangunan } \\
\text { (Lopo) Di Lasiana (WBU1) }\end{array}$ & 2.476 & .000 \\
\hline $\begin{array}{l}\text { Kenyamanan Taman/ } \\
\text { Kebun Di Lasiana (WBU2) }\end{array}$ & -2.475 & .001 \\
\hline
\end{tabular}




\begin{tabular}{|l|c|c|}
\hline $\begin{array}{l}\text { Kenyamanan Bangunan } \\
\text { Konvensi/ Tempat } \\
\text { Pertemuan (WBU3) }\end{array}$ & 1.201 & .068 \\
\hline $\begin{array}{l}\text { Kenyamanan Bangunan } \\
\text { Kantin/ Kuliner (WBU4) }\end{array}$ & 1.485 & .015 \\
\hline
\end{tabular}

Dengan demikian, berdasarkan hasil uji regresi logistic biner, maka didapatkan rumus indeks potensi wisata buatan (Attractions) adalah sebagai beikut :

Indeks Potensi Wisata Buatan (IPWBU) $=-2.236$ $+2.47 \mathrm{WBU} 1-2.475 \mathrm{WBU} 2+1.201 \mathrm{WBU} 3+1.48 \mathrm{WBU} 4$ IPWBU $=2,236+2.47(0,49)-2,475(0,26)+1,201$ $(0,18)+1,48(0,58)=\mathbf{- 0 . 5 8 8 7 8}$

Nilai cut off $=0$

Berdasarkan nilai cut off tersebut dapat dibuat 2 kategori yaitu:

Skor indeks $<\mathbf{0}=$ diprediksi potensi wisata buatan belum memadai

Skor indeks $\geq \mathbf{0}=$ diprediksi potensi wisata buatan sudah memadai

Berdasarkan hasil penilaian untuk indeks potensi wisata buatan (IPWBU) maka skor yang didapatkan sebesar $\mathbf{- 0 . 5 8 8 7 8}$ artinya kondisi wisata buatan di pantai Lasiana dirasakan masih belum memadai sehingga di perlukan langkah-langkah perbaikan untuk obyek wisata buatan yang ada di pantai lasiana sehingga dapat menarik minat wisatawan untuk datang ke pantai Lasiana.

\section{b) ACCESSIBILITIES}

Variabel Aksesibilitas (Accsess), merupakan penghubung wisatawan dalam menjangkau objek wisata, seperti: transportasi, jalan, dan pintu masuk lainya. Variabel bebas yang diduga mempengaruhi wisatawan untuk berkunjung objek wisata pantai lasiana adalah Kemudahan Rute Jalan Menuju Lasiana, Kondisi Jalan Utama menuju Lasiana, Keberadaan Papan Petunjuk arah menuju lasiana, Kemudahan akses Lasiana, Kondisi jalan masuk lasiana, Keberadaan transportasi umum, Kemudahan akses transsportasi umum dan Biaya tiket masuk.

\section{- Uji Signifikansi Model}

Berdasarkan perhitungan analisis logistic biner, didapatkan hasil nilai statistik G2 ini mengikuti distribusi Khi-kuadrat dengan derajat bebas $p$ sehingga Ho ditolak karena p-value $>\alpha(11.000>$ $0,1)$, yang artinya terdapat paling sedikit ada satu atau lebih indikator yang berpengaruh signifikan terhadap variabel aksesibilitas.

Tabel 10 Uji Signifikansi Variabel Aksesibilitas

\begin{tabular}{|l|r|r|c|}
\hline Step & $\begin{array}{c}-2 \text { Log } \\
\text { likelihood }\end{array}$ & $\begin{array}{c}\text { Cox \& Snell } \\
\text { R Square }\end{array}$ & $\begin{array}{c}\text { Nagelkerke } \\
\text { R Square }\end{array}$ \\
\hline 1 & $11.000^{\mathrm{a}}$ & .750 & 1.000 \\
\hline
\end{tabular}

\section{- Uji Parsial dan Pembentukan Model}

Variabel bebas yang diduga mempengaruhi wisatawan untuk berkunjung objek wisata pantai lasiana adalah Kemudahan Rute Jalan Menuju
Lasiana (AC1), Kondisi Jalan Utama menuju Lasiana (AC2), Keberadaan Papan Petunjuk arah menuju lasiana (AC3), Kemudahan akses Lasiana (AC4), Kondisi jalan masuk lasiana (AC5), Keberadaan transportasi umum (AC6), Kemudahan akses transsportasi umum dan Biaya tiket masuk (AC7). Hasil uji wald dapat dilihat pada tabel dibawah ini :

Tabel 11 Uji Wald Variabel Aksesibilitas

\begin{tabular}{|cc|c|c|c|}
\hline & & B & Wald & Sig. \\
\hline \multirow{4}{*}{ AC1(1) } & 1.921 & 3.179 & .075 \\
& AC2(1) & -2.039 & 1.614 & .024 \\
& AC3(1) & -.340 & .104 & .047 \\
$1^{\mathrm{a}}$ & AC4(1) & 4.265 & 17.342 & .000 \\
& AC5(1) & 2.784 & 1.618 & .023 \\
& AC6(1) & 1.628 & .899 & .343 \\
& AC7(1) & -1.011 & .325 & .568 \\
& AC8(1) & -1.254 & .305 & .581 \\
& Constant & -2.655 & 1.748 & .186 \\
\hline
\end{tabular}

Berdasarkan hasil analisis, indikator AC1, AC2, $\mathrm{AC} 3, \mathrm{AC} 4$ dan AC5 mempunyai pengaruh secara signifikan terhadap variabel Aksesibilitas dan tiga indikator lainnya tidak berpengaruh (AC6, AC7 dan AC8).

\section{- Odds Ratio}

Berdasarkan hasil perhitungan, diperoleh nilai koefisien masing-masing indikator untuk variabel aksesibilitas yang berguna dalam perumusan indeks potensi aksesibilitas (Accessibilities) OWPL.

Hasil perhitungan menunjukkan bahwasannya ada 5 (lima) indikator (AC1, AC2, AC3, AC4 dan AC5) yang berpegaruh secara signifikan terhadap variabel aksesibilitas (Accessibilities), dan 3 (tiga) indikator (AC6, AC7 dan AC8) yang tidak berpengaruh secara signifikan. Sehingga hanya lima indikator yang berpengaruh secara signifikan saja yang digunakan dalam perumusan indeks.

Berdasarkan hasil perhitungan, diketahui bahwa nilai odds rasio terbesar terdapat pada indikator "Keberadaan Papan Petunjuk arah menuju lasiana" dan yang terkecil terdapat pada indikator "Biaya tiket masuk". Hasil perhitungan odds ratio dapat dilihat pada tabel di bawah ini :

Tabel 12 Hasil Perhitungan Odds Ratio Variabel Aksesibilitas

\begin{tabular}{|l|c|c|}
\hline \multicolumn{1}{|c|}{ Variabel } & Koefisien & $\begin{array}{c}\text { Nilai } \\
\text { P }\end{array}$ \\
\hline $\begin{array}{l}\text { Kemudahan Rute Jalan } \\
\text { Menuju Lasiana }\end{array}$ & 1.921 & .075 \\
\hline $\begin{array}{l}\text { Kondisi Jalan Utama } \\
\text { menuju Lasiana }\end{array}$ & -2.039 & .024 \\
\hline $\begin{array}{l}\text { Keberadaan Papan } \\
\text { Petunjuk arah menuju }\end{array}$ & -.340 & .047 \\
\hline
\end{tabular}




\begin{tabular}{|l|c|c|}
\hline lasiana & & \\
\hline $\begin{array}{l}\text { Kemudahan akses } \\
\text { Lasiana }\end{array}$ & 4.265 & .000 \\
\hline $\begin{array}{l}\text { Kondisi jalan masuk } \\
\text { lasiana }\end{array}$ & 2.784 & .023 \\
\hline $\begin{array}{l}\text { Keberadaan transportasi } \\
\text { umum }\end{array}$ & 1.628 & .343 \\
\hline $\begin{array}{l}\text { Kemudahan akses } \\
\text { transsportasi umum }\end{array}$ & -1.011 & .568 \\
\hline Biaya tiket masuk & -1.254 & .581 \\
\hline
\end{tabular}

Dengan demikian, berdasarkan hasil uji regresi logistic biner, maka didapatkan rumus indeks potensi aksesibilitas (Accessibilities) adalah sebagai beikut :

Indeks Potensi Aksesibilitas (IPAc) $=-2,655+$ $1.921 \mathrm{AC} 1-2.039 \mathrm{AC} 2-0.340 \mathrm{AC} 3+4.265 \mathrm{AC} 4+$ 2.784AC5

IPAc $=-2,655+1.921(0,98)-2.039(0,96)-0.340$ $(0,78)+4.265(0,98)+2.78(0,94)=\mathbf{3 . 8 0 1 6}$

Nilai cut off $=0$

Berdasarkan nilai cut off tersebut dapat dibuat 2 kategori yaitu:

Skor indeks $<\mathbf{0}=$ diprediksi potensi aksesibilitas (Accessibilities) belum memadai

Skor indeks $\geq \mathbf{0}=$ diprediksi potensi aksesibilitas (Accessibilities) sudah memadai

Berdasarkan hasil penilaian untuk indeks potensi Aksesibilitas (IPAc) maka skor yang didapatkan sebesar $\mathbf{3 , 8 0 1 6}$, artinya wisatawan mudah mengakses lokasi wisata pantai lasiana. Dari lima indikator yang berpengaruh secara signifikan, indikator ketersediaan papan petunjuk arah menuju destinasi wisata yang masih kurang.

Pelayanan kepada wisatawan tidak hanya berfokus pada lokasi destinasi wisata. Pelayanan itu harus dimulai sejak awal kedatangan wisatawan hingga kepulangannya. Terkait dengan hal ini maka aksesibilitas menuju dan kembali dari destinasi perlu disiapkan sebaik mungkin antara lain dengan ketersediaan informasi petunjuk arah. Ketersediaan informasi petunjuk arah dimaksudkan untuk membantu wisatawan mencapai dan kembali dari destinasi wisata. Selain melalui signboard (papan petunjuk arah), di lokasi-lokasi strategis perlu didirikan tourism information center (TIC) tempat di mana para wisatawan bisa mendapatkan segala informasi yang dibutuhkan tentang sebuah destinasi wisata termasuk tentang bagaimana mereka dapat mencapai destinasi tersebut. Di destinasi wisata, papan petunjuk arah/ signboard sebaiknya tidak hanya berisi keterangan tentang arah melainkan juga keterangan lain seperti bagaimana wisatawan harus berperilaku di destinasi wisata dan keterangan tentang obyek wisata tersebut.

\section{c) ACCOMMODATION}

Penelitian ini menggunakan analisis Regresi Logistik untuk mengidentifikasi indikator yang mempengaruhi keputusan wisatawan untuk berkunjung ke objek wisata pantai lasiana berdasarkan potensi akomodasi. Variabel yang berpengaruh adalah kenyamanan penginapan dan ketersediaan jumlah penginapan. Hasil pengolahan data responden dari penyebaran kuisioner dengan model Regresi Logistik akomodasi, sebagian besar wisatawan menyatakan bahwa penginapan di OWPL dirasa masih kurang nyaman dan tidak ada pilihan lain selain penginapan yang ada sekarang yaitu OCD.

\section{- Uji Signifikansi Model}

Berdasarkan perhitungan analisis logistic biner, didapatkan hasil nilai statistik G2 ini mengikuti distribusi Khi-kuadrat dengan derajat bebas $p$ sehingga Ho ditolak karena p-value $>\alpha(117.575>$ $0,1)$, yang artinya terdapat paling sedikit ada satu atau lebih indikator yang berpengaruh signifikan terhadap variable akomodasi.

Tabel 13 Uji Signifikansi Variabel Akomodasi

\begin{tabular}{|l|c|r|c|}
\hline Step & $\begin{array}{c}-2 \text { Log } \\
\text { likelihood }\end{array}$ & $\begin{array}{c}\text { Cox \& Snell } \\
\text { R Square }\end{array}$ & $\begin{array}{c}\text { Nagelker } \\
\text { ke R } \\
\text { Square }\end{array}$ \\
\hline 1 & $117.575^{\mathrm{a}}$ & .075 & .105 \\
\hline
\end{tabular}

\section{- Uji Parsial dan Pembentukan Model}

Berdasarkan hasil analisis uji wald, indikator kenyamanan penginapan (AK1) dan ketersediaan jumlah penginapan (AK2) berpengaruh secara signifikan terhadap variabel akomodasi secara bersama- sama, hal ini tercermin dengan nilai $\mathrm{p}$ Value $<0,01$ untuk masing- masing indikator sehingga ke dua indikator tersebut berpengaruh terhadap variabel akomodasi. Hasil uji wald dapat dilihat pada tabel dibawah ini :

Tabel 14 Uji Wald Variabel Akomodasi

\begin{tabular}{|ll|r|r|r|}
\hline & & \multicolumn{1}{|c|}{ B } & \multicolumn{1}{c|}{ Wald } & \multicolumn{1}{c|}{ Sig. } \\
\hline Step & AK1(1) & 38.713 & 22.000 & .0998 \\
$1^{\text {a }}$ & AK2(1) & -19.741 & 23.000 & .0999 \\
& Constant & .677 & 9.417 & .002 \\
\hline
\end{tabular}

\section{- Odds Ratio}

Berdasarkan hasil perhitungan, diperoleh nilai koefisien masing-masing indikator untuk variabel akomodasi yang berguna dalam perumusan indeks potensi akomodasi Obyek Wisata Pantai Lasiana. Hasil perhitungan odds ratio dapat dilihat pada tabel dibawah ini :

Tabel 15 Hasil Perhitungan Odds Ratio Variabel Akomodasi

\begin{tabular}{|l|r|r|}
\hline \multicolumn{1}{|c|}{ Variabel } & Koefisien & Nilai P \\
\hline \multicolumn{1}{|c|}{ Akomodasi } & & \\
\hline $\begin{array}{l}\text { Kenyamanan } \\
\text { penginapan (AK1) }\end{array}$ & 38.713 & .0998 \\
\hline $\begin{array}{l}\text { Ketersediaan (jumlah) } \\
\text { penginapan (AK2) }\end{array}$ & -19.741 & .0999 \\
\hline
\end{tabular}


Nilai $\mathrm{P}$ menunjukkan nilai signifikasi masingmasing indikator terhadap variabel akomodasi OWPL. Hasil perhitungan menunjukkan semua indikator berpengaruh secara signifikan terhadap variabel potensi akomodasi, sehingga seluruh indikator digunakan dalam perumusan indeks.

Berdasarkan tabel perhitungan di atas, diketahui bahwa nilai odds rasio terbesar terdapat pada indikator "kenyamanan kondisi fasilitas penginapan" dan yang terkecil terdapat pada indikator "Ketersediaan jumlah penginapan". Semakin besar nilai odds pada masing- masing indikator, maka semakin besar pula peluang responden untuk berkunjung kembali karena alasan indikator tersebut.

Dengan demikian, berdasarkan hasil uji regresi logistic biner, maka didapatkan rumus indeks akomodasi adalah sebagai beikut :

$$
\begin{aligned}
& \text { Indeks Potensi Akomodasi }(\text { IPAk })=0,677+ \\
& \begin{aligned}
& 38.713 \text { AK } 1-19.741 \mathrm{AK} 2 \\
& \text { IPAk }=0,677+38,713(0,07)-19,741(0,03) \\
&=\mathbf{2 , 7 9 4 6 8}
\end{aligned}
\end{aligned}
$$

Nilai cut off $=0$

Berdasarkan nilai cut off tersebut dapat dibuat 2 kategori yaitu:

Skor indeks $<\mathbf{0}=$ diprediksi potensi fasilitas akomodasi belum memadai

Skor indeks $\geq \mathbf{0}=$ diprediksi potensi fasilitas akomodasi sudah memadai

Berdasarkan hasil penilaian untuk indeks potensi Akomodasi (IPAk) maka skor yang didapatkan sebesar 2,79468, artinya wisatawan sudah merasa puas dengan kondisi dan ketersediaan akomodasi di OWPL dan sekitarnya. Angka indeks ini tidak hanya menggambarkan kondisi akomodasi di OWPL saja tetapi juga kondisi akomodasi yang berada di sekitar OWPL yang relatif dekat dengan kota Kupang. Ketersediaan akomodasi di OWPL tidak terlalu penting bagi wisatawan yang datang berkunjung oleh sebab faktor letak OWPL yang relatif mudah dan murah dijangkau karena berada tidak jauh dari Kota Kupang. Dari kondisi ini, pemerintah disarankan untuk mengembangkan variable 4 A lain yang belum optimal.

\section{d) AMENITIES}

Variabel Amenities, merupakan segala sesuatu yang terdapat di objek wisata yang mampu menunjang kebutuhan wisatawan seperti: restaurant, Money Changer, Hotel, dan lain sebagainya. Variabel bebas yang diduga mempengaruhi wisatawan untuk berkunjung objek wisata pantai lasiana adalah: Fasilitas tempat sampah (AM1), Kenyamanan tempat parkir (AM2), Kenyamanan fasilitas toilet (AM3), Ketersediaan jumlah toilet (AM4), Ketersediaan guide di lasiana (AM5), Ketersediaan loket karcis masuk (AM6), Ketersediaan penjaga pantai (AM7), Keberagaman kuliner (AM8), Ketersediaan jumlah kantin (AM9), Kenyamanan kantin (AM10),
Ketersediaan jasa penyewaan alat berenang (AM11), Ketersediaan fasilitas bermain anak (AM12), Kenyamanan tempat wisata (AM13), Ketersediaan jumlah penginapan di lasiana (AM14), Ketersediaan fasilitas air bersih (AM15) dan Ketersediaan fasilitas air minum (AM16).

\section{- Uji Signifikansi Model}

Untuk mengetahui pengaruh indikator terhadap variabel Amenities secara bersama-sama (overal) di dalam model, dapat menggunakan Uji Likelihood Ratio. Berdasarkan perhitungan analisis logistic biner, didapatkan hasil nilai statistik G2 ini mengikuti distribusi Khi-kuadrat dengan derajat bebas $\mathrm{p}$ sehingga Ho ditolak karena $\mathrm{p}$-value $>\alpha$ $(21.000>0,1)$, yang artinya terdapat paling sedikit ada satu atau lebih indikator yang berpengaruh signifikan terhadap variable Amenities.

Tabel 16 Uji Signifikansi Variabel Amenities

\begin{tabular}{|l|c|c|c|}
\hline Step & $\begin{array}{c}-2 \text { Log } \\
\text { likelihood }\end{array}$ & $\begin{array}{c}\text { Cox \& Snell } \\
\text { R Square }\end{array}$ & $\begin{array}{c}\text { Nagelkerke R } \\
\text { Square }\end{array}$ \\
\hline 1 & $21.000^{\mathrm{a}}$ & .712 & 1.000 \\
\hline
\end{tabular}

\section{- Uji Parsial dan Pembentukan Model}

Pengujian keberartian parameter (koefisien $\beta$ ) secara parsial untuk variabel amenities dapat dilakukan melalui Uji Wald. dengan hipotesisnya sebagai berikut:

Ho: $\beta \mathrm{j}=0$ (variabel bebas ke $\mathrm{j}$ tidak mempunyai pengaruh secara signifikan terhadap variabel tidak bebas

$\mathrm{H} 1: \beta \mathrm{j} \neq 0$ (variabel bebas ke $\mathrm{j}$ mempunyai pengaruh secara signifikan terhadap variabel tidak bebas)

Berdasarkan hasil analisis uji wald, indikator AM1 s/d AM16 berpengaruh secara signifikan terhadap variable Amenities secara bersama- sama, hal ini tercermin dengan nilai $\mathrm{p}$-Value $<0,1$ untuk semua indikator sehingga disimpulkan bahwa masing-masing indikator berpengaruh terhadap variable Amenities. Hasil uji wald dapat dilihat pada tabel dibawah ini :

Tabel 17 Uji Wald Variabel Amenities

\begin{tabular}{|l|r|r|r|}
\hline & \multicolumn{1}{|c|}{ B } & Wald & \multicolumn{1}{c|}{ Sig. } \\
\hline AM1 & 275.990 & 11.001 & .0979 \\
AM2 & 201.302 & 12.001 & .0980 \\
AM3 & 43.854 & 11.000 & .0989 \\
AM4 & 181.682 & 12.001 & .0981 \\
AM5 & -72.016 & 12.000 & .0997 \\
AM6 & 46.704 & 11.000 & .0988 \\
AM7 & -89.280 & 13.001 & .0982 \\
AM8 & 16.334 & 12.000 & .0997 \\
AM9 & 59.385 & 12.000 & .0983 \\
AM10 & .630 & 10.000 & .090 \\
AM11 & 76.609 & 11.000 & .0984 \\
AM12 & 111.073 & 11.000 & .0996 \\
AM13 & -.133 & 16.000 & .0800 \\
AM14 & 95.137 & 12.000 & .0880 \\
AM15 & -261.410 & 12.000 & .0970
\end{tabular}




\begin{tabular}{|l|r|r|r|} 
AM16 & 7.989 & 18.000 & .0560 \\
Constant & -293.375 & .001 & .000 \\
\hline
\end{tabular}

\section{- Odds Ratio}

Berdasarkan hasil perhitungan odds ratio, diperoleh nilai koefisien masing-masing indikator untuk variabel Amenities yang berguna dalam perumusan indeks potensi Amenities di Pantai Lasiana.

Nilai P menunjukkan nilai signifikasi masingmasing indikator terhadap variabel Amenities di pantai Lasiana. Hasil perhitungan menunjukkan ada 16 (enam belas) indikator yang berpengaruh secara signifikan terhadap variabel Amenities. Sehingga 16 (enam belas) indikator yang berpegaruh secara signifikan terhadap variabel potensi Amenities yang digunakan dalam perumusan indeks. Berdasarkan perhitungan, diketahui bahwa nilai odds ratio terbesar terdapat pada indikator "ketersediaan fasilitas tempat sampah" dan yang terkecil terdapat pada indikator "keberadaan fasilitas ATM". Semakin besar nilai odds pada masing- masing indikator, maka semakin besar pula peluang responden untuk berkunjung kembali karena alasan indikator tersebut.

Dengan demikian, berdasarkan hasil uji regresi logistic biner, maka didapatkan rumus indeks potensi Amenities adalah sebagai beikut :

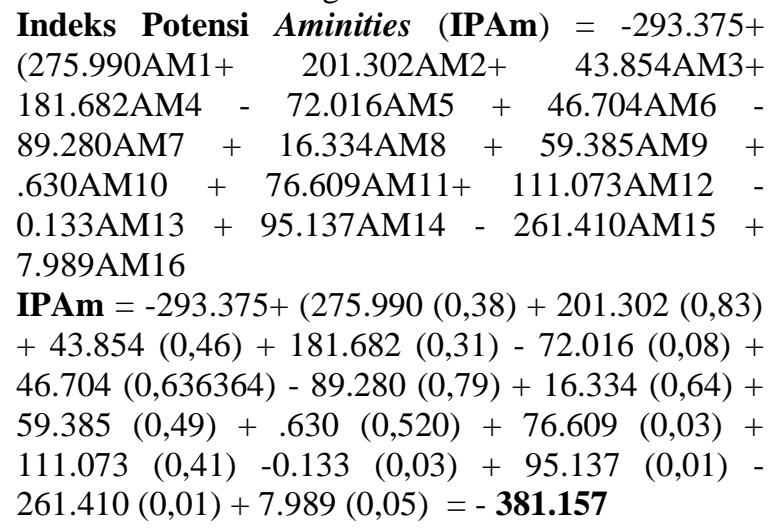

Nilai cut off $=0$

Berdasarkan nilai cut off tersebut dapat dibuat 2 kategori yaitu:

Skor indeks $<\mathbf{0}=$ diprediksi potensi fasilitas buatan (Amenities) belum memadai

Skor indeks $\geq \mathbf{0}=$ diprediksi potensi fasilitas buatan (Amenities) sudah memadai

Berdasarkan hasil penilaian untuk indeks potensi Amenities (IPAm) maka skor yang didapatkan sebesar $\mathbf{- 3 8 1 . 1 5 7}$, artinya wisatawan belum merasa puas dengan kondisi amenities di OWPL. Kepuasaan pengunjung tidak semata-mata ditentukan oleh keberadaan atraksi pantai Lasiana, tetapi juga dipengaruhi oleh ketersediaan fasilitasfasilitas penunjang (amenities) seperti fasilitas tempat sampah, fasilitas parkir, fasilitas toilet, kuliner yang beragam, fasilitas arena bermain anak, sarana air bersih, dll. Dari hasil analisis ditemukan bahwa frekuensi ketidaktersediaan fasilitas penunjang masih kecil. Oleh karena itu, hal yang perlu dilakukan oleh pemerintah daerah khususnya Perangkat Daerah terkait adalah membangun lebih banyak fasilitasfasilitas penunjang tersebut. Upaya ini dapat dilakukan dengan melibatkan/melakukan kerjasama dan koordinasi dengan pihak ketiga atau stakeholder terkait misalnya terkait tempat parkir, toilet, tempat kuliner, dan terkait tempat sampah dan pengelolaannya.

\section{e) AWARENESS}

Menurut Chafid Fandeli (2000), obyek wisata adalah perwujudan dari ciptaan manusia, tata hidup, seni budaya serta sejarah bangsa dan tempat atau keadaan alam yang mempunyai daya tarik untuk dikunjungi wisatawan dan memiliki komponen yang harus ada untuk mendukung suatu daerah tujuan wisata, salah satunya adalah awareness. Variabel bebas yang diduga mempengaruhi wisatawan untuk berkunjung objek wisata pantai lasiana berdasarkan variable awareness adalah Keterlibatan masyarakat sekitar dalam bidang ekonomi (AW1), Keterlibatan masyarakat sekitar dalam bidang kuliner (AW2), Keterlibatan masyarakat sekitar dalam bidang penyewaan alat berenang (AW3), Keterlibatan masyarakat sekitar dalam bidang ekonomi kreatif (souvenir) (AW4), Keterlibatan masyarakat sekitar dalam bidang keamanan lasiana (AW5), Keterlibatan masyarakat sekitar dalam bidang pemeliharaan fasilitas umum lasiana (AW6), dan Keterlibatan masyarakat sekitar dalam bidang kelestarian lingkungan lasiana (AW7).

\section{- Uji Signifikansi Model}

Berdasarkan perhitungan analisis logistic biner, didapatkan hasil nilai statistik G2 ini mengikuti distribusi Khi-kuadrat dengan derajat bebas $p$ sehingga Ho ditolak karena p-value $>\alpha(10.00997>$ $0,1)$, yang artinya terdapat paling sedikit ada satu atau lebih indikator yang berpengaruh signifikan terhadap variable Awareness.

Tabel 18 Uji Signifikansi Variabel Awareness

\begin{tabular}{|l|c|c|c|}
\hline Step & $\begin{array}{c}-2 \text { Log } \\
\text { likelihood }\end{array}$ & $\begin{array}{c}\text { Cox \& Snell } \\
\text { R Square }\end{array}$ & $\begin{array}{c}\text { Nagelkerke } \\
\text { R Square }\end{array}$ \\
\hline 1 & $10.00997^{\mathrm{a}}$ & .375 & .874 \\
\hline
\end{tabular}

\section{- Uji Parsial dan Pembentukan Model}

Berdasarkan hasil analisis uji wald, indikator AW1 s/d AW7 berpengaruh secara signifikan terhadap variabel Awareness secara bersama- sama, hal ini tercermin dengan nilai $\mathrm{p}$-Value $<0,01$ untuk masing-masing indikator sehingga masing- masing indikator berpengaruh terhadap variabel Awareness. Hasil uji wald dapat dilihat pada tabel dibawah ini : 
Tabel 19 Uji Wald Variabel Awareness

\begin{tabular}{|ll|c|c|c|}
\hline & & B & Wald & Sig. \\
\hline Step & AW1 & 41.495 & 8.983 & .0998 \\
$1^{\mathrm{a}}$ & AW2 & -19.119 & 9.234 & .0999 \\
& AW3 & -.117 & 9.322 & .0990 \\
& AW4 & -.081 & 5.344 & .0880 \\
& AW5 & -.040 & 2.332 & .0999 \\
& AW6 & -.004 & 20.129 & .0455 \\
AW7 & .029 & 21.222 & .0223 \\
& Constant & -1.099 & 1.810 & .178 \\
\hline
\end{tabular}

\section{- Odds Ratio}

Berdasarkan hasil perhitungan odds ratio, diperoleh nilai koefisien masing-masing indikator untuk variabel awareness yang berguna dalam perumusan indeks potensi awareness di Obyek Wisata Pantai Lasiana. Hasil perhitungan odds ratio dapat dilihat pada tabel dibawah ini :

Tabel 20 Hasil Perhitungan Odds Ratio Variabel Awareness

\begin{tabular}{|c|c|c|}
\hline Variabel & Koefisien & Nilai P \\
\hline Awareness & & \\
\hline AW1 & 41.495 & .0998 \\
\hline AW2 & -19.119 & .0999 \\
\hline AW3 & -.117 & .0990 \\
\hline AW4 & -.081 & .0880 \\
\hline AW5 & -.040 & .0999 \\
\hline AW6 & -.004 & .0455 \\
\hline AW7 & .029 & .0223 \\
\hline
\end{tabular}

Nilai P menunjukkan nilai signifikasi masingmasing indikator terhadap variabel awareness. Hasil perhitungan menunjukkan semua indikator berpengaruh secara signifikan terhadap variabel awareness, sehingga seluruh indikator digunakan dalam perumusan indeks.

Berdasarkan tabel perhitungan di atas, diketahui bahwa nilai odds rasio terbesar terdapat pada indikator "Keterlibatan masyarakat sekitar dalam bidang kelestarian lingkungan lasiana" dan yang terkecil terdapat pada indikator "Keterlibatan masyarakat sekitar dalam bidang ekonomi kreatif (souvenir)". Semakin besar nilai odds pada masingmasing indikator, maka semakin besar pula peluang responden untuk berkunjung kembali karena alasan indikator tersebut. Dengan demikian, berdasarkan hasil uji regresi logistic biner, maka didapatkan rumus indeks awareness adalah sebagai beikut :

Indeks Potensi Awareness (IPAw) $=-1.099+$ (41.495AW1-19.119AW2-0.117AW3- 0.081AW4 0.040AW5 -0.004AW6+ 0.029AW7)
IPAw $=-1.099+41.495(0)-19.119(0,9)-0.117$

$(0,61) \quad-0.081 \mathrm{AW} 4(0,29)-0.040(0,292929)-0.004$

$(0,393939)+0.029(0,37)=\mathbf{- 1 8 , 4 0 3 5}$

Nilai cut off $=0$

Berdasarkan nilai cut off tersebut dapat dibuat 2 kategori yaitu:

Skor indeks $<\mathbf{0}=$ diprediksi potensi awareness belum memadai

Skor indeks $\geq \mathbf{0}=$ diprediksi potensi awareness sudah memadai

Berdasarkan hasil penilaian untuk indeks Awareness (IPAw) maka skor yang didapatkan sebesar $\mathbf{- 1 8 , 4 0 3 5}$, artinya penduduk sekitar tempat wisata belum sadar dan ikut terlibat dalam aktivitas pariwisata pantai lasiana. Hal ini perlu menjadi perhatian sebab untuk mencapai tujuan pengembangan pariwisata yang memberikan manfaat berkelanjutan di bidang ekonomi, sosial budaya dan lingkungan dibutuhkan peran serta semua stakeholder yang terlibat di dalamnya khususnya masyarakat di sekitar destinasi pariwisata.

Keterlibatan masyarakat di sekitar destinasi wisata sebagi wujud sikap sadar wisata antara lain dapat diamati dari keterlibatan mereka dalam bidang ekonomi baik dengan mengembangkan kuliner, penyewaan alat berenang maupun pembuatan hasil kerajinan untuk dapat dijual kepada wisatawan. Selain itu, kesadaran masyarakat juga tercermin dari tingkat partisipasi masyarakat dalam upaya menjaga situasi kondusif di destinasi wisata (keamanan), pemeliharaan fasilitas umum dan perlindungan lingkungan.

Upaya untuk meningkatkan kesadaran masyarakat di bidang pariwisata tentu saja didasari oleh kondisi existing yang justru menunjukkan bahwa kesadaran tersebut masih rendah. Upaya untuk meningkatkan sikap sadar wisata masyarakat haruslah merupakan upaya untuk meningkatkan pengetahuan dan pengalaman yang mereka miliki. Oleh karena itu, dibutuhkan peningkatan fungsi edukasi sadar wisata. Hal ini berarti, perlu disediakan program berkala sosialisasi sadar wisata bagi masyarakat di sekitar destinasi yang belum memiliki kesadaran pariwisata untuk meningkatkan pemahaman mereka tentang peluang dan tantangan di dunia pariwisata.

Selain melalui instansi terkait yang membidangi kepariwisataan, fungsi edukasi/sosialisasi sadar wisata dapat dilakukan dengan melibatkan institusi seperti perguruan tinggi dan lembaga swadaya masyarakat. Materi sosialisasi sadar wisata antara lain mencakup peran serta masyarakat dalam mewujudkan sapta pesona pariwisata. Selain itu, materi edukasi/sosialisasi sadar wisata juga dapat terdiri dari pembinaan untuk meningkatkan keterampilan masyarakat agar dapat menangkap peluang ekonomi dari destinasi pariwisata di wilayahnya. Demikianlah, perlu dilaksanakan program-program yang mendukung dan membangun 
kapasitas masyarakat di sekitar destinasi dan program yang mendorong industri (pariwisata) untuk membeli produk dan jasa di destinasi wisata. Di destinasi wisata Pantai Lasiana belum tersedia produk-produk souvenir/ cinderamata untuk dijual kepada wisatawan. Oleh karena itu, perlu dibangun sebuah tempat khusus untuk menjual berbagai cinderamata. Terkait dengan ini, masyarakat lokal perlu diberikan pelatihan-pelatihan untuk meningkatkan kreatifitas dalam menghasilkan sebuah karya seni atau produk lain yang dapat dijual kepada para wisatawan.

\section{Kesimpulan}

Berdasarkan hasil analisis dan pembahasan di atas, maka dapat disimpulkan beberapa hal :

1. Indikator yang berpengaruh terhadap Variabel 5A di Obyek Wisata Pantai Lasiana adalah :

Variabel Attraction ; (1) Wisata Alam dipengaruhi oleh indikator Keindahan Pantai (WA1), Pemandangan Laut (AW2), Pemandangan Sunset Dan Sunrise (AW3), Keindahan Pasir Pantai (AW4), Keberadaan Tumbuhan Pantai (AW5), Kenyamanan Cuaca Di Pantai (AW6) dan Keindahan Air Laut (AW7); (2) Wisata budaya dipengaruhi oleh indikator Suguhan Musik / Teater (WB2); (3) Wisata buatan dipengaruhi oleh indikator Kenyamanan Bangunan (Lopo) Di Lasiana (WBU1), Kenyamanan Taman/ Kebun Di Lasiana (WBU2), Kenyamanan Bangunan Konvensi/ Tempat Pertemuan (WBU3) dan Kenyamanan Bangunan Kantin/ Kuliner (WBU4).

- Variabel Accesibilities dipengaruhi oleh indikator Kondisi jalan masuk lasiana (AC1), Kemudahan akses Lasiana (AC2), Keberadaan Papan Petunjuk arah menuju lasiana (AC3), Kondisi Jalan Utama menuju Lasiana (AC4) dan Kemudahan Rute Jalan Menuju Lasiana (AC5).

Variabel Amenities dipengaruhi oleh indikator Fasilitas tempat sampah (AM1), Kenyamanan tempat parkir (AM2), Kenyamanan fasilitas toilet (AM3), Ketersediaan jumlah toilet (AM4), Ketersediaan guide di lasiana (AM5), Ketersediaan loket karcis masuk (AM6), Ketersediaan penjaga pantai (AM7), Keberagaman kuliner (AM8), Ketersediaan jumlah kantin (AM9), Kenyamanan kantin (AM10), Ketersediaan jasa penyewaan alat berenang (AM11), Ketersediaan fasilitas bermain anak (AM12), Kenyamanan tempat wisata (AM13), Ketersediaan jumlah penginapan di lasiana (AM14), Ketersediaan fasilitas air bersih (AM15) dan Ketersediaan fasilitas air minum (AM16).

- Variabel Akomodasi dipengaruhi oleh indikator kenyamanan penginapan (AK1) dan ketersediaan jumlah penginapan (AK2).

- Variabel Awareness dipengaruhi oleh indikator Keterlibatan masyarakat sekitar dalam bidang ekonomi (AW1), Keterlibatan masyarakat sekitar dalam bidang kuliner (AW2), Keterlibatan masyarakat sekitar dalam bidang penyewaan alat berenang (AW3), Keterlibatan masyarakat sekitar dalam bidang ekonomi kreativ (souvenir) (AW4), Keterlibatan masyarakat sekitar dalam bidang keamanan lasiana (AW5), Keterlibatan masyarakat sekitar dalam bidang pemeliharaan fasilitas umum lasiana (AW6), Keterlibatan masyarakat sekitar dalam bidang kelestarian lingkungan lasiana (AW7).

2. Rumus indeks untuk masing- masing variabel (5A) yang dihasilkan dari kajian ini adalah sebagai berikut :

\section{A. VARIABEL ATTRACTION}

- Wisata Alam

$$
\begin{array}{ll}
\text { Indeks }= & -62,744+65,161 \mathrm{WA} 1+ \\
\text { Wisata Alam } & 15.385 \mathrm{WA} 2+14.695 \mathrm{WA} 3- \\
(\text { IPWA }) & 1 \mathrm{WA} 4+15.101 \mathrm{WA}+ \\
& 15.861 \mathrm{WA}+33.643 \mathrm{WA} 7 \\
= & -62,744+65,161(0,95)+ \\
& 15.385(0,92)+14.695(0,91)- \\
& 1(0,77)+15,101(0,78) \\
& +15,861(0,58)+33,643(0,61) \\
& =\mathbf{6 7 , 4 1 6 0}
\end{array}
$$

Berdasarkan penilaian indeks wisata alam (IPWA) diperoleh skor sebesar 67, 4160. Hal ini berarti bahwa kondisi wisata alam di OWPL sudah cukup memadai, meliputi keindahan pantai dan pemandangan lautnya, pemandangan sunset dan sunrise yang indah, cuaca pantai yang nyaman untuk dikunjungi berkaitan erat dengan keberadaan tumbuhan pantai yaitu pohon lontar yang tumbuh di area wisata serta kejernihan air laut pantai lasiana. Keindahan ini menjadi modal alam yang dimiliki oleh obyek wisata Pantai Lasiana yang perlu dijaga dan dikembangkan.

\begin{tabular}{|c|c|c|}
\hline $\begin{array}{l}\text { Wisata Buatan } \\
\text { Indeks Wisa }\end{array}$ & & \\
\hline $\begin{array}{l}\text { Buatan } \\
\text { (IPWBu) }\end{array}$ & & $\begin{array}{l}2.475 \mathrm{WBU} 2+1.201 \mathrm{WBU} 3+ \\
1.485 \mathrm{WBU} 4\end{array}$ \\
\hline & $=$ & $\begin{array}{l}2,236+2.476(0,49)- \\
2,475(0,26)+1,201(0,18)\end{array}$ \\
\hline
\end{tabular}

\section{- Wisata Budaya}

$$
\begin{aligned}
& \text { Indeks }=-4.751+5.064 \mathrm{WB} 2 \\
& \text { Wisata } \\
& \text { Budaya } \\
& \text { (IPWB) } \\
& =-4,751+5,064(0,08)=\mathbf{- 4 , 3 4 5 9}
\end{aligned}
$$

Berdasarkan hasil penilaian atas indeks wisata budaya (IPWB), skor yang didapatkan adalah sebesar - 4,3459. Hal ini berarti bahwa kondisi wisata budaya di pantai lasiana dirasa kurang memadai untuk menarik minat wisatawan berkunjung ke Obyek Wisata Pantai Lasiana. 
FLOBAMORA, Desember 2019, Vol 2, No.2, pp. 20-38 http://www.flobamora.e-journal.id 32 p-ISSN 0216-2741; e-ISSN 2686-6188

$$
+1,485(0,58)=\mathbf{- 0 . 5 8 8 7 8}
$$

Berdasarkan hasil penilaian untuk indeks wisata buatan (IPWBU) maka skor yang didapatkan sebesar $\mathbf{- 0 . 5 8 8 7 8}$ artinya kondisi wisata buatan belum memadai sehingga masih perlu perbaikan-perbaikan untuk atraksi wisata buatan di pantai lasiana.

\section{B. VARIABEL ACCESSIBILITIES}

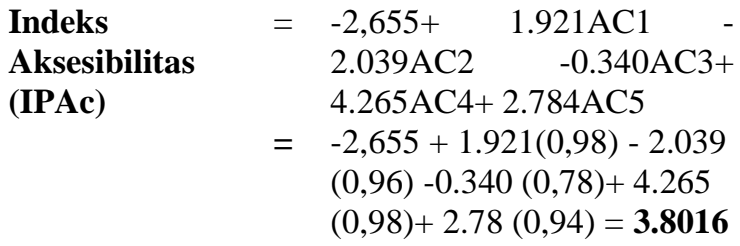

Berdasarkan hasil penilaian untuk indeks Aksesibilitas (IPAc) maka skor yang didapatkan sebesar 3,8016, artinya wisatawan mudah mengakses lokasi wisata pantai lasiana. Dari lima indikator yang berpengaruh secara signifikan pada variabel, indikator ketersediaan papan petunjuk arah menuju destinasi wisata yang masih kurang.

\section{VARIABEL AMENITIES}

\begin{tabular}{|c|c|c|}
\hline $\begin{array}{l}\text { Indeks } \\
\text { Amenities } \\
\text { (IPAm) }\end{array}$ & $=$ & $\begin{array}{l}-293.375+\quad(275.990 A M 1+ \\
\text { 201.302AM2+43.854AM3+ } \\
\text { 181.682AM4 - 72.016AM6 + } \\
\text { 46.704AM7-89.280AM8 } \\
\text { +16.334AM9+59.385AM10+ } \\
.630 A M 11+76.609 \text { AM12+ } \\
\text { 111.073AM13 -0.133AM14 } \\
\text { +95.137AM15-261.41AM16 } \\
\text { +7.989AM18-451.28AM21) } \\
-293.375+(275.990 \quad(0,38)+ \\
\text { 201.302 }(0,83)+43.854(0,46)+ \\
\text { 181.682 }(0,31)-72.016(0,08)+ \\
\text { 46.704 }(0,636364)-89.280 \\
(0,79)+16.334(0,64)+59.385 \\
(0,49)+.630(0,520)+76.609 \\
(0,03)+111.073(0,41)-0.133 \\
(0,03)+95.137(0,01)- \\
261.41(0,01)+7.989(0,05)- \\
451.289(0,02))=-381.157\end{array}$ \\
\hline
\end{tabular}

Berdasarkan hasil penilaian untuk indeks Amenities (IPAm) maka skor yang didapatkan sebesar- 381.157, artinya wisatawan belum merasa puas dengan kondisi amenities di Pantai Lasiana. Kepuasaan pengunjung tidak semata-mata ditentukan oleh keberadaan atraksi pantai Lasiana, tetapi juga dipengaruhi oleh ketersediaan fasilitas-fasilitas penunjang (amenities) seperti fasilitas tempat sampah, fasilitas parkir, fasilitas toilet, kuliner yang beragam, fasilitas arena bermain anak, sarana air bersih, dll.

\section{VARIABEL ACCOMODATION}

$$
\begin{array}{lll}
\begin{array}{l}
\text { Indeks } \\
\begin{array}{l}
\text { Akomodasi } \\
\text { (IPAk) }
\end{array}
\end{array} & 0,677+38.713 \text { AK } 1- \\
& \\
& =\quad 0,677+38,713(0,07)- \\
& 19,741(0,03)=\mathbf{2 , 7 9 4 6 8}
\end{array}
$$

Berdasarkan hasil penilaian untuk indeks potensi Akomodasi (IPAk) maka skor yang didapatkan sebesar $\mathbf{2 , 7 9 4 6 8}$, artinya wisatawan sudah merasa puas dengan kondisi dan ketersediaan akomodasi di Pantai Lasiana. Angka indeks ini tidak hanya menggambarkan kondisi akomodasi di Obyek Wisata Pantai Lasiana saja tetapi juga kondisi akomodasi yang berada di sekitar Obyek Wisata Pantai Lasiana yang relatif dekat dengan kota Kupang. Ketersediaan akomodasi di Obyek Wisata Pantai Lasiana tidak terlalu penting bagi wisatawan yang datang berkunjung oleh sebab faktor letak Obyek Wisata Pantai Lasiana yang relatif mudah dan murah dijangkau karena berada tidak jauh dari Kota Kupang.

\section{E. VARIABEL AWARENESS \\ Indeks \\ Awareness \\ $=-1.099+(41.495 \mathrm{AW} 1-$ \\ (IPAw) 19.119AW2-0.117AW3- 0.081AW4 -0.040AW5 - $0.004 \mathrm{AW} 6+0.029 \mathrm{AW7})$ \\ $=-1.099+41.495(0)-19.119$ $(0,9) \quad-0.117 \quad(0,61)$ $0.081 \mathrm{AW} 4 \quad(0,29) \quad-0.040$ $(0,292929)-$ $0.004(0,393939)+\quad 0.029$ $(0,37)=\mathbf{- 1 8 , 4 0 3 5}$}

Berdasarkan hasil penilaian untuk indeks Awareness (IPAw) maka skor yang didapatkan sebesar - 18,4035, artinya penduduk sekitar tempat wisata belum sadar dan ikut terlibat dalam aktivitas pariwisata pantai lasiana baik keterlibatan dalam bidang ekonomi, bidang kuliner, dalam bidang ekonomi kreatif (souvenir), dalam bidang pemeliharaan fasilitas umum, dll.

\section{Ucapan Terima Kasih}

Ucapan terima kasih disampaikan kepada Bappeda Provinsi NTT sebagai lembaga penyedia dana untuk kegiatan pengkajian ini.

\section{Referensi}

Cohen E. (1979). The Impact of Tourism on the Hill Tribes of Northern Thailand.Int. Asien forum (10/1), 5-38. Diunduh pada tanggal 14 Agustus 2018, dari www.cabdirect.org

Damanik, Janianton. (2013). Pariwisata Indonesia (Antara Peluang dan Tantangan).Yogyakarta: Pustaka Pelajar. 
Erisman HM. 1983. Tourism and cultural dependency in theWest Indies.Annals of Tourism Research (10/3), 337-361. Diunduh pada tanggal 25 Agustus 2018, dari https://www.researchgate.net/publication

Garson, D.G. (2008). Factor Analysis: Statnotes. Diunduh pada tanggal 9 Desember 2018 darihttp://www2.chass.nesu.edu/garson/ pa765/factor.htm

Gunawan, Myra dan Olivert Ortis.(2012). Rencana Strategis Pariwisata Berkelanjutan dan Green Jobs untuk Indonesia. Jakarta: ILO Indonesia.

Hadiwijoyo, Surya Sakti. (2012). Perencanaan Pariwisata Perdesaan Berbasis Masyarakat (Sebuah Pendekatan Konsep). Yogyakarta: Graha Ilmu.

Hofstede, Geert, Geert Jan Hofstede, Michael Minkov. (1997). Cultures and Organization: Software of the Mind. New York: Mc Graw Hill.

Hosmer, D.W dan S. Lemeshow.(2000). Apllied Logistic Regression. New York: John Willey \& Sons

Kleinbaum, D.G. (1994). Logistic Regression A Self Learning Text.New York: SpringerVerlag

Laiskodat, Viktor Bungtilu. (2018). Pariwisata Nusa Tenggara Timur: Potensi dan Dinamika. Salatiga: Satya Wacana University Press.

Laws, Eric. (1995). Tourist Destinatioin Management: Issues, Analysis and Policies. Michigan: Routledge.

MacCannell D. (1984).Reconstructed Ethnicity Tourism and Cultural Identity in Third World Communities.Annals of Tourism Research (11/3), 375-39. Diunduh pada tanggal 20 Agustus 2018, dari https://eurekamag.com/research

Mansperger MC. (1995). Tourism and Cultural Change in Small-Scale Societies.Human Organization (77/2), 87-94. Diunduh pada tanggal 15 Agustus 2018, dari sfaajournals.net.

Middleton, Victor T.C dan Jackie Clarke. (2001). Marketing in Travel and Tourism Assesssment of Nvqs and Svqs Series Tourism. London: Routledge.

Mousavi, Seyed Sina dkk. (2016). Defining Cultural Tourism. International Conference on
Civil, Architecture and Sustainable Development (CASD-2016). Diunduh pada tanggal 10 Agustus 2018, dari https://doi.org/10.15242/IICBE.DIR1216 $\underline{411}$

Nafilla, Oktaniza. (2010). Peran Komunitas Kreatif dalam Pengembangan Pariwisata Budaya di Situs Megalitikum Gunung Padang.Jurnal Perencanaan Wilayah dan Kota, ( 24/ 1) 65-80. Diunduh pada tanggal 13 Agustus 2018, dari http://www.sappk.itb.ac.id.

Peraturan Menteri Pariwisata Nomor 14 Tahun 2016 Tentang Pedoman Destinasi Pariwisata Berkelanjutan

Pitana, I. Gede dan Gayatri, Putu G. (2005).Sosiologi Pariwisata. Yogyakarta: Andi.

Richards, Greg. (1996). Cultural Tourism in Europe. Wallingford UK: CAB International.

Rosenberg H. 1988.A Negotiated World. Toronto: Univ. Toronto Press

Rossel P. (1988). Tourism: Manufacturing the Exotic. Copenhagen: IWGIA.

Sunaryo, Bambang. (2013). Kebijakan Pembangunan Destinasi Pariwisata Konsep dan Aplikasinya di Indonesia.Yogyakarta: Gava Media.

Suwena, I. Ketut dan I. Gst. Ngr Widyatmaja.(2010). Pengetahuan Dasar Ilmu Pariwisata. Denpasar: Udayana University Press.

Undang-Undang Republik Indonesia Nomor 10 Tahun 2009 Tentang Kepariwisataan

Urry, J. (1990) The Tourist Gaze: Leisure and Travel in Contemporary Societies. London: SAGE. Diunduh pada tanggal 13 Agustus 2018, dari https://books.google.com/books

Van den Berghe P. (1994). The Quest for the Other: Ethnic Tourism in San Crist'obal, Mexico. Seattle: Univ. Wash. Press. 